Eur $\mathrm{J}$ Clin Chem Clin Biochem

$1995 ; 33: 411-415$

(c) 1995 Walter de Gruyter \& Co.

Berlin - New York

\title{
Oral Intake of Selenium Has no Effect on the Serum Concentrations of Growth Hormone, Insulin-Like Growth Factor-1, Insulin-Like Growth Factor-Binding Proteins 1 and 3 in Healthy Women
}

\author{
By Helle M. Meltzer' and Egil Haug ${ }^{2}$ \\ 1 University of Oslo, Nordic School of Nutrition, Faculty of Medicine, Blindern, Oslo, Norway \\ 2 The Hormone Laboratory, Aker University Hospital, 0514 Oslo, Norway
}

(Received January 2/May 2, 1995)

Summary: The administration of large doses of selenium (Se) to rats leads to reduced serum levels of somatotropin (growth hormone) and insulin-like growth factor-1 (IGF-1), followed by growth retardation. Similar experiments in humans have been contradictory. The effects of wheat Se and selenomethionine supplementation were investigated in healthy, Norwegian women. In study 1, the participants $(n=18)$ were given Se-rich bread with 100, 200 and $300 \mu \mathrm{g}$ Se daily for 6 weeks. Initial serum Se concentration were $1.5 \pm 0.2 \mu \mathrm{mol} / 1$ (mean $\pm \mathrm{SD}$ ). Serum Se increased in a dose-dependent manner in the three groups $(p<0.001)$. There was no effect on somatotropin and IGF-1 at any of the Se doses given. In study $2(n=24)$, the effects of $400 \mu \mathrm{g}$ selenomethionine daily for 15 weeks were studied in a placebo controlled study. In the treatment group, serum Se concentrations increased by more than $100 \%$. There was, however, no effect on serum somatotropin and IGF-1 concentrations, nor was there any effect on IGF-binding proteins 1 and 3. Our results indicate that at normal or slightly increased intakes, Se has no effect on the serum concentrations of these two hormones in healthy individuals.

\section{Introduction}

Growth retardation is a typical finding in animals exposed to toxic doses of selenium $(\mathrm{Se})(1,2,3)$. It is also a regular finding in stocks with alkali disease, a Se toxicity syndrome (for review, 1.c. $(4,5)$ ). Growth retardation seems to appear irrespective of Se being administered in an inorganic or organic form $(6,7)$. Recently, Thorlacius-Ussing and coworkers reported that somatotropin treatment of selenite exposed rats restored their normal growth rate although serum insulin like growth factor 1 (IGF-1) concentrations were still subnormal (8, 9). Moreover, when selenite exposure was discontinued, serum somatotropin concentrations returned to normal while IGF-1 concentrations remained low.

In a Danish Se supplementation trial $256 \mu \mathrm{g}$ yeast Se was given daily to rheumatics for six months, leading to a significant reduction in the serum concentration of IGF-1 (10). The results of the animal studies and the study in humans prompted the health authorities in Den- mark and Norway to warn against Se supplements in 1989.

Due to import of Se-rich wheat from USA and Canada, wheat is the main dietary source of Se in Norway. At least $50 \%$ of the Se in wheat is in the form of selenomethionine (11), which is also used in a number of commercial Se supplements. Numerous studies have demonstrated that selenomethionine, as well as wheat Se, has high bioavailability $(12-16)$. The purpose of the two studies presented here was to study the effects of increasing daily amounts of wheat $\mathrm{Se}$ and selenomethionine on the serum concentrations of somatotropin, IGF1, IGF-binding protein 1 and IGF-binding protein 3 in healthy, young, Norwegian women.

\section{Methods}

We report here the results from two studies. Study 1 was conducted in 1989 with graded doses of wheat selenium, and the serum levels 
of Se have been published previously (15). Unpublished results from that study indicated that wheat Se had no effects on serum growth hormone and IGF-1 concentrations. However, IGF-1 circulates bound to specific binding proteins, and it was important to see wether Se treatment affected serum levels of these binding proteins. Moreover, one could not exclude the possibility that somewhat higher Se doses might have an effect. A new study was, therefore, carried out in 1992 (study 2), with selenomethionine given at the highest level that is, generally, deemed safe, and serum levels of IGF binding proteins were measured.

\section{Subjects}

Study 1: Eighteen female students at the age of 20-26 volunteered to participate in the study, and written consent was given by each subject, in complicance with the ethical standards then in use.

Study 2: Twenty-four female students at the age of 20-40 participated. All participants gave informed consent and the study protocol was approved by the Regional Ethics Committee of Medical Research, Region II, Norway.

None of the participants in the two studies had taken Se-containing supplements the last three months prior to the studies. They were all in good health, and they were non-smokers. None of the subjects were pregnant or lactating, and they used no medication. Four participants in study 1 and seven in study 2 used oral contraceptives. In study 1; all subjects were encouraged to maintain their usual daily routines and dietary habits during the study. In study 2 , 16 out of the 24 participants were encouraged to eat as much fish as possible, at least three dinner servings per week, during the study. As the fish eating had no influence on any of the results reported here, 'eaters and non-eaters' of fish were pooled in the subsequent analyses. The initial values of serum Se, body mass index and age are given in table 1.

\section{Experimental design}

Study 1: The subjects were randomized into three groups. For six weeks the participants were given Se-rich bread, group $1(n=6)$ receiving $100 \mu \mathrm{g}$, group $2(n=6) 200 \mu \mathrm{g}$ and group $3(n=6) 300$ $\mu \mathrm{g}$ Se per day. The slices replaced bread otherwise consumed during the day.

Study 2: The subjects were randomized into 2 groups. Group 1 $(n=16)$ received $400 \mu \mathrm{g} \mathrm{Se}$ in the form of selenomethionine containing tablets daily, while group $2(n=8)$ received placebo tablets for 15 weeks.

\section{Samples}

Blood samples were obtained by venipuncture in the morning after a 12-hour fast, in study 1 at weeks 0,3 and 6, and in study 2 at weeks 0 and 15 .

\section{Diet and supplements}

Study 1: Whole grain wheat containing $10 \mathrm{mg} / \mathrm{kg}$ Se was obtained from Mr. R. Marts, Bonesteel, South Dakota with the kind assistance of Prof. O. E. Olson of South Dakota State University. The wheat was ground, mixed with appropriate amounts of ordinary Norwegian flour, and baked into bread giving 100, 200 and 300 $\mu \mathrm{g}$ Se per $100 \mathrm{~g}$ of bread, respectively.

Study 2: Selenomethionine and placebo tablets were kindly provided by Pharma Nord A/S, Denmark. The tablets were identical in taste and appearance. Each active tablet contained $100 \mu \mathrm{g}$ selenomethionine, and both groups were given 4 tablets per day.

Previous analysis of Se intake in similar groups of Norwegian women, using the duplicate portion technique, indicated a mean dietary Se intake of $80 \mu \mathrm{g} / 10 \mathrm{MJ}$ (17). With an average energy intake of $9.2 \mathrm{MJ} /$ day, the daily Se intake was estimated to be approximately $75 \mu \mathrm{g}$. Accordingly, the total Se intake in the intervention period in study 1 , corrected for the substituted normal bread slices, was estimated to be $160 \mu \mathrm{g}, 260 \mu \mathrm{g}$ and $360 \mu \mathrm{g}$ Se daily for the three groups, respectively. In study 2 the total average Se intake would be approximately $475 \mu \mathrm{g} / \mathrm{d}$ in the study group and 75 $\mu \mathrm{g} / \mathrm{d}$ in the control group.

$$
\cdot 1
$$

\section{Analytical methods}

The concentrations of Se in serum and blood were determined by atomic absorption spectrometry using a hydride generator system (Varian AA-1475, VGA-76) after digestion in a mixture of nitric and perchloric acid $(18,19)$. The results are expressed in $\mu \mathrm{mol} / \mathrm{l}$.

Somatotropin was measured using an immunoradiometric assay developed at the Hormone laboratory. The intra- and inter-assay precisions are $6 \%$ and $10 \%$, respectively. The normal range for women is $0.6-7.2 \mathrm{mIU} / 1$.

IGF-1 was measured after extraction ( $C-18)$ using a radioimmunoassay from Nichols Institute Diagnostics (USA). The intra- and inter-assay precisions are $7 \%$ and $12 \%$, respectively. The normal range for women is $15-35 \mathrm{nmol} / \mathrm{l}$.

IGF binding protein-1 was measured using an immunofluorometric assay developed at the Hormone laboratory. The intra- and interassay precisions are $8 \%$ and $16 \%$, respectively. The normal range for women is $0.02-0.47 \mathrm{nmol} / \mathrm{l}$.

IGF binding protein-3 was measured using a radioimmunoassay from Diagnostic System Laboratories (USA). The intra- and interassay precisions are $5 \%$ and $8 \%$, respectively. The reference range for women is $63-280 \mathrm{nmol} / 1$.

\section{Statistics}

The large variances observed for some of the quantities measured in this study are normal and may be an indicator for the use of non-parametric statistics. In the present study, non-parametric methods were in a few cases more powerful than the parametric, but in no case did they give significant results. For conceptual simplicity and ease of comparisons, we have therefore reported the parametric results. Thus the changes in the clinical findings within groups were tested for significance by paired t-test. Means between the three groups were subjected to one-way analysis of variance and compared by Duncan's multiple range test. A p-value less than 0.05 was considered statistically significant. The results are expressed as mean $\pm \mathrm{SD}$.

Tab. 1 Initial values (mean $\pm \mathrm{SD}$ ) of serum Se, body mass index (BMI) and age.

\begin{tabular}{|c|c|c|c|c|}
\hline & n & $\begin{array}{l}\text { Serum } \\
\text { Se } \\
(\mu \mathrm{mol} / 1)\end{array}$ & $\begin{array}{l}\text { BMA } \\
\left(\mathrm{kg} / \mathrm{m}^{2}\right. \\
\text { height) }\end{array}$ & $\begin{array}{l}\text { Age } \\
\text { (years) }\end{array}$ \\
\hline Study 1: & ' & & & \\
\hline $\begin{array}{l}\text { Group 1: }(100 \mu \mathrm{g} / \mathrm{d} \mathrm{Se}) \\
\text { Group 2: }(200 \mu \mathrm{g} / \mathrm{d} \mathrm{Se}) \\
\text { Group 3: }(300 \mu \mathrm{g} / \mathrm{d} \mathrm{Se})\end{array}$ & $\begin{array}{l}6 \\
6 \\
6\end{array}$ & $\begin{array}{l}1.4 \pm 0.1 \\
1.5 \pm 0.2 \\
1.6 \pm 0.2\end{array}$ & $\begin{array}{l}21 \pm 1 \\
20 \pm 3 \\
21 \pm 1\end{array}$ & $\begin{array}{l}24 \pm 2 \\
23 \pm 3 \\
23 \pm 2\end{array}$ \\
\hline \multicolumn{5}{|l|}{ Study 2: } \\
\hline $\begin{array}{l}\text { Group 1: }(400 \mu \mathrm{g} / \mathrm{d} \mathrm{Se}) \\
\text { Group 2: (placebo) }\end{array}$ & $\begin{array}{r}16 \\
8\end{array}$ & $\begin{array}{l}1.3 \pm 0.1 \\
1.3 \pm 0.2\end{array}$ & $\begin{array}{l}21 \pm 2 \\
22 \pm 3\end{array}$ & $\begin{array}{l}22 \pm 1 \\
25 \pm 7\end{array}$ \\
\hline
\end{tabular}




\section{Results}

\section{Serum and blood Se concentrations}

The initial serum concentrations of Se were similar in the different study groups in both studies (tab. 1). Serum Se increased, as previously reported, in a dose-related manner in study 1 , i.e. by $0.25,0.47$ and $0.67 \mu \mathrm{mol} / 1$ in the three groups, respectively $(p<0.001$ (15). In the selenomethionine-group (study 2), Se concentrations increased by 1.99 and $3.29 \mu \mathrm{mol} / 1(\mathrm{p}<0.001)$ in serum and blood, respectively. Serum and blood concentrations of Se were strongly correlated throughout the study. There was no change in serum or blood Se concentrations in the placebo group.

\section{Somatotropin}

Study 1: As shown in table 2, initial somatotropin concentrations varied between the groups, groups 1 and 2 being significantly different, $p<0.05$, from group 3 .
Mean concentrations for all groups increased by week three (NS) and increased further in groups 1 and 2 by week six (NS), while in group 3 a decline was found after 6 weeks, resulting in almost identical growth hormone concentrations by the end of the supplementation period.

Study 2: There was a non-significant decline in somatotropin concentrations in the placebo group, but the two groups had comparable concentrations during the whole study (tab. 2).

\section{Insulin-like growth factor- 1 and binding proteins}

At group level, the elevated serum concentrations of Se were not accompanied by altered IGF-1 concentrations in any of the studies (tab. 2). Neither were there any changes in IGF binding protein-1 and IGF binding protein-3 in the Se-supplemented groups in study 2, while

Tab. 2 Serum levels of somatotropin, IGF-1, IGF binding protein-1 and IGF binding protein-3.

\begin{tabular}{|c|c|c|c|c|c|}
\hline & Start & & Midway & Final & \\
\hline \multicolumn{6}{|l|}{ Somatotropin $(\mu l U / l)$} \\
\hline \multicolumn{6}{|l|}{ Study $1:$} \\
\hline Group $1(100 \mu \mathrm{g} / \mathrm{d} \mathrm{Se})$ & 6.0 & $\pm 5.5^{\mathrm{a}}$ & $12.6 \pm 8.1$ & 16.0 & \pm 11.3 \\
\hline Group $2(200 \mu \mathrm{g} / \mathrm{d} \mathrm{Se})$ & 7.8 & \pm 4.1 & $11.7 \pm 6.2$ & 17.2 & \pm 12.1 \\
\hline Group $3(300 \mu \mathrm{g} / \mathrm{d} \mathrm{Se})$ & 13.4 & $\pm 4.9^{\mathrm{b}}$ & $19.7 \pm 8.9$ & 16.9 & \pm 9.7 \\
\hline \multicolumn{6}{|l|}{ Study 2: } \\
\hline Group $1(400 \mu \mathrm{g} / \mathrm{d} \mathrm{Se})$ & 15.0 & \pm 13.1 & & 12.0 & \pm 9.8 \\
\hline Group 2 (placebo) & 25.2 & \pm 19.1 & & 17.0 & \pm 14.4 \\
\hline
\end{tabular}

IGF-1 (nmol/1)

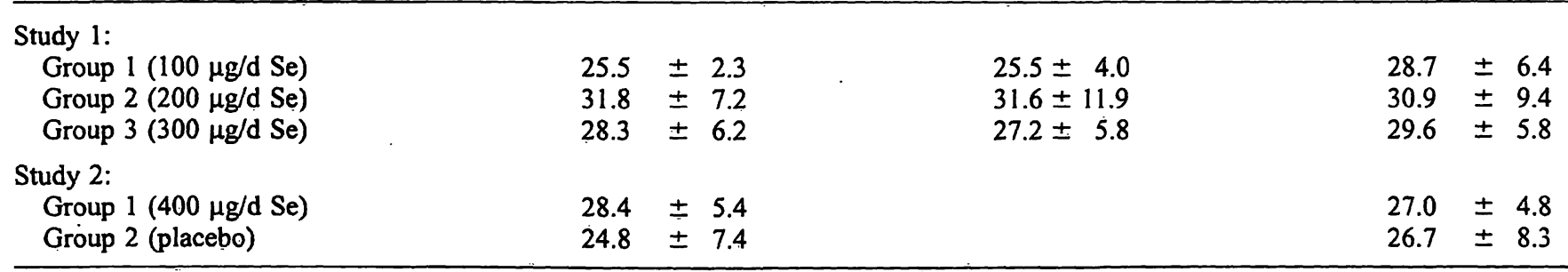

IGF binding protein-1 (nmol/1)

Study 2:

$\begin{array}{llr}\text { Group } 1(400 \mu \mathrm{g} / \mathrm{d} \mathrm{Se}) & 0.100 \pm 0.12 & 0.104 \pm 0.10 \\ \text { Group 2 (placebo) } & 0.166 \pm 0.18 & 0.097 \pm 0.06\end{array}$

IGF binding protein-3 (nmol/l)

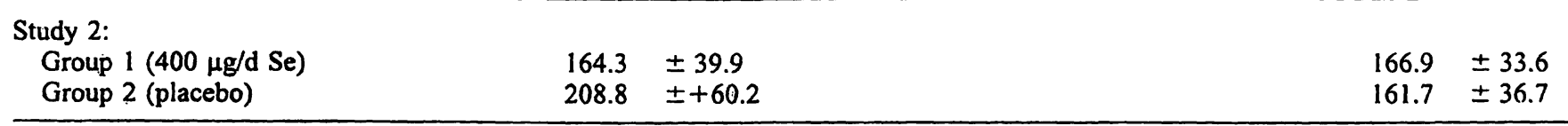

Study 1: Somatotropin and IGF-1 initially, and after 3 and 6 weeks. Results with different superscription letters denote values signifiStudy 2: Somatotropin, IGF-1, IGF binding protein-1 and IGF bonding protein-3 initially and after 15 weeks of supplementation. cantly different at a given time $(p<0.05 ;$ Duncant's multiplerange test). 
the concentration of both IGF-binding proteins decreased (NS) in the placebo group (tab. 2).

\section{Correlations}

There were no correlations between the serum levels of Se and somatotropin in any of the study groups during the two studies. The concentrations of serum Se correlated weakly and positively (NS) with IGF-1 at the start of the study in study 1 , while the correlation was negative (NS) in study $2(r=-0.40, p=0.054)$. Blood Se and serum IGF-1 concentrations showed a significant, negative correlation at the start of study $2: \mathrm{r}=-0.54$, $p=0.007$, the corresponding correlation between serum Se and IGF-1 being $r=-0.40, p=0.054$. There was, however, no correlation between these quantities at the end of the study (fig. 1). Moreover, there was no correlation between changes in the concentrations of serum Se and IGF-1 in the two studies.

Neither initial IGF binding protein-1 and IGF binding protein-3 concentrations nor changes in these analyses correlated with 'serum Se concentrations at any point during study 2 .

\section{Discussion}

Animal studies have shown that strongly increased blood Se values are associated with decreased serum
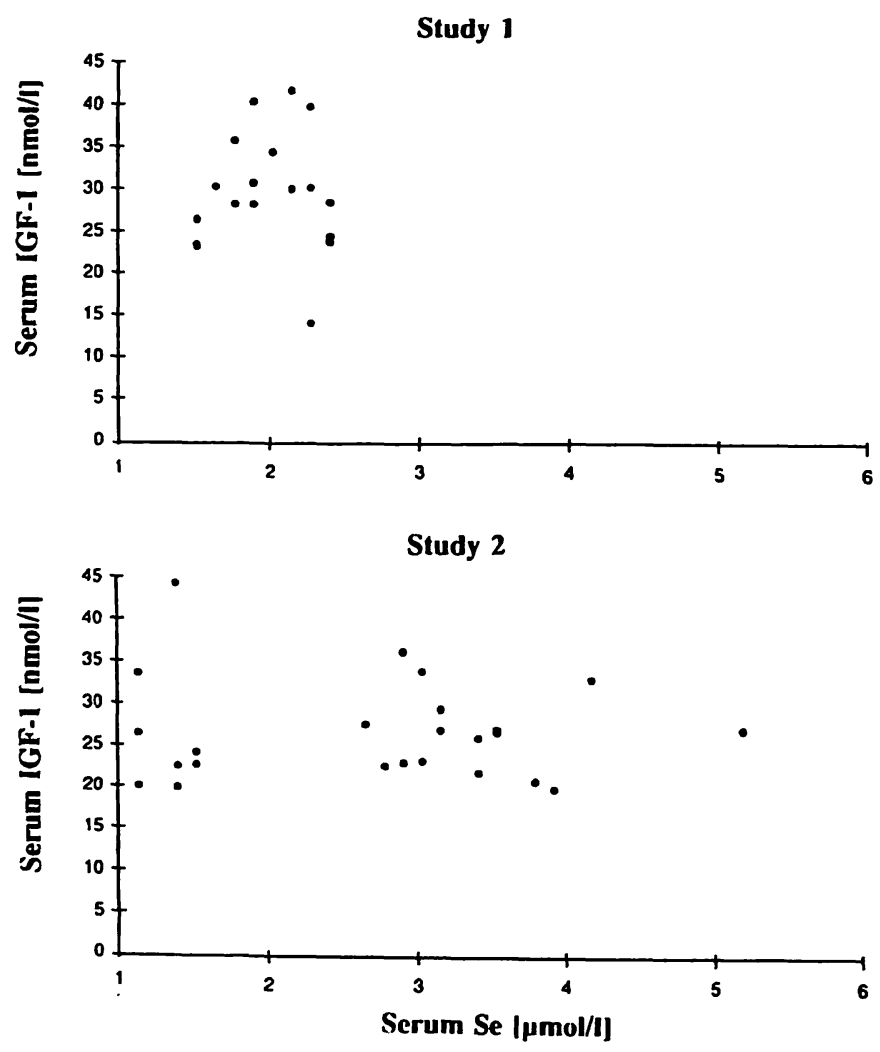

Fig. 1 IGF-1 versus serum Se concentrations at the end of study 1 and study 2 . In study $1, r=0.03$ (NS), in study $2, r=-0.002$ (NS). levels of IGF-1, suggesting that Se may suppress the secretion of growth hormone and/or IGF-1 (8-10). Our data show, however, that normal or moderately increased serum and blood concentrations of Se (1.3$4.0 \mu \mathrm{mol} / \mathrm{l})$, corresponding to a supplementation with wheat Se or selenomethionine in the $100-400 \mu \mathrm{g}$ range, have no effects on growth hormone and IGF-1 concentrations in healthy individuals. Our data do not rule out the possibility that higher Se intake may lower growth hormone and IGF-1 concentrations. Such serum concentrations would, however, approach sub-toxic levels, and have little relevance regarding the safety of normal Se supplementation (50-400 $\mu \mathrm{g} / \mathrm{d})$. Though our study groups were fairly small, we would have detected a $15 \%$ average decrease in IGF-1 concentrations as significant, a much smaller decrease than observed by the Danish group mentioned earlier. The modest IGF-1 lowering we observed in study 2 would require 290 supplemented subjects to attain signficance, and the clinical relevance of this may well be questioned.

The negative correlation between IGF-1 and blood Se seen at the start of study 2 should not be interpreted as a causal relationship between the two quantities, since this correlation disappeared upon Se supplementation. The lack of correlation between serum (and blood) levels of Se and IGF-1 in both studies corresponds well with the findings of Salbe et al. (20), who found no relation between serum Se and IGF-1 concentrations in an epidemiological study in USA.

A Se-induced lowering of IGF-binding proteins, would increase the clearance rate of IGF-1 (21), and thus be a possible mechanism by which Se might lower IGF-1. We found, however, no indication of a suppression of either IGF binding protein-1 or IGF binding protein-3. On the contrary, we observed a weak positive correlation between changes in IGF binding protein-3 and serum$\mathrm{Se}$, all subjects taken together. Thus, whatever influence the IGF-binding proteins may have on IGF-1 serum levels and bioavailability (21), moderate variations in serum Se do not seem to have any impact in healthy individuals.

The metabolism of Se seems to be perturbed in rheumatoid arthritis (22). In this patient group, Se incorporation into the Se-dependent enzyme glutathione peroxidase ${ }^{1}$ ) is suppressed, and the polymorphonuclear leukocytes, that ordinarily are among the Se-richest cells in the body, do not increase their Se content in response to $\mathrm{Se}$ supplementation (22). In a rat model, high-dose selenite supplementation resulted in a high accumulation of $\mathrm{Se}$ in the anterior pituitary, especially in the secretory gran-

1) Glutathione peroxidase (EC 1.11.1.9) 
ules of the somatotrophs (23). The Se accumulation resulted in impaired pituitary and hepatic function. It may be speculated that a redistribution of Se may explain the IGF-1 lowering effect of Se supplementation observed in rheumatoid arthritis (10). Models for normal selenomethionine kinetics are developed in 1. c. (24). It may also be speculated that the circulating proteolytic activity observed during several illness conditions (21), and responsible for IGF binding protein-3 degradation, is somehow effected by Se.

In summary, our results show that moderate Se supplementation has no significant effects on serum levels of growth hormone, IGF-1, IGF binding protein-1 and IGF binding protein-3. Our results are thus in accordance with the lack of epidemiological evidence for growth retardation in moderately high-selenium areas of the world.

\section{Acknowledgements}

We are indebted to the late Gunnur Norheim for advice and encouragement. Excellent technical assistance was provided by $A$. Godal, Department of Pharmacology and Toxicology, National Veterinary Institute, and $A$. Jorgensen at the Institute for Nutrition Research. The excellent technical assistance of $B$. Inglingstad and $T$. Arnesen at the Hormone Laboratory is gratefully acknowledged. We are also indebted to our $18+24$ female participants who cooperated so willingly.

\section{References}

1. Moxon AL. Alkali disease or selenium poisoning. South Dakota Agric Exp Sta Bull 1937; 311:1-91.

2. Halverson AW, Palmer IS, Guss PL. Toxicity of selenium to post weanling rats. Toxicol Appl Pharmacol 1966; 9:477-84.

3. Palmer IS, Olson OE. Relative toxicities of selenite and selenate in the drinking water of rats. J Nutr 1974; 104:306-14.

4. Shamberger RJ. Toxicity of selenium. In: Frieden E. editor. Biochemistry of selenium, vol. 2. New York/London: Plenum, 1983:185-206.

5. Olson OE. Selenium toxicity in animals with emphasis on man. J Am Coll Toxicol 1986; 5:45-70.

6. Goehring TB, Palmer IS, Olson OE, Libal GW, Wahlstrom RC. Effects of seleniferous grains and inorganic selenium on tissue and blood composition and growth performance of rats and swine. J Anim Sci 1984; 59:725-32.

7. McAdam PA, Levander OA. Chronic toxicity and retention of dietary selenium fed to rats as D- or L-selenomethionine, selenite, or selenate. Nutr Res 1987; 7:601-10.

8. Thorlacius-Ussing $\mathrm{O}$, Flyvbjerg A, Jørgensen $\mathrm{KD}$, Ørskov $\mathrm{H}$. Growth hormone restores normal growth in selenium-treated rats without increase in circulating somatomedin C. Acta Endocrinol (Copenh) 1988; 117:65-72.

9. Thorlacius-Ussing O, Flyvbjerg A, Ørskov H. Growth in young rats after termination of sodium selenite exposure: studies of growth hormone and somatomedin C. Toxicol 1988; 48:167-76

10. Thorlacius-Ussing O, Flyvbjerg A, Tarp U, Overvad K, Ørskov $\mathrm{H}$. Selenium intake induces growth retardation through reversible growth hormone and irreversible somatomedin $C$ suppression. In: Wendel $A$, editor. Selenium in biology and medicine. Heidelberg: Springer-Verlag, 1989:126-9.

11. Olson OE, Novacek EJ, Whitehead EI, Palmer IS. Investigations on selenium in wheat. Phytochemistry 1970; 9:1181-8.

12. Levander OA, Alfthan G, Arvilommi H, Huttunen JK. Kataja $\mathrm{M}$, Koivistoinen $\mathrm{P}$, et al. Bioavailability of selenium to Finnish men as assessed by platelet gluthatione peroxidase activity and other blood parameters. Am J Clin Nutr 1983; 37:887-97.

13. Thomson CD, Ong LK, Robinson MF. Effects of supplementation with high-selenium wheat bread on selenium, glutathione peroxidase and related enzymes in blood components of New Zealand residents. Am J Clin Nutr 1985; 41:1015-22.

14. Luo X, Wei H, Yang C, Xing J, Liu X, Qiao C, et al. Bioavailability of selenium to residents in a low-selenium area of China. Am J Clin Nutr 1985; 42:439-48.

15. Meltzer HM, Norheim G, Loken EB, Holm H. Supplementation with wheat selenium induces a dose-dependent response in serum and urine of a Se-replete population. Br J Nutr 1992; 67:287-94

16. Meltzer HM; Bibow K, Paulsen IT, Mundal H, Norheim G, Holm H. Different bioavailability in humans of wheat and fish selenium as measured by blood platelet response to increased dietary Se. Biol Trace Elem Res 1993; 36:229-41.

17. Meltzer HM, Norheim G, Bibow K, Myhre K, Holm H. The form of selenium determines the response to supplementation in a selenium replete population. Eur J Clin Nutr 1990; $44: 435-46$

18. Norheim G, Haugen A. Precise determination of selenium in tissues using automated wet digestion and an automated hydride generator-atomic absorption spectroscopy system. Acta Pharmacol Toxicol 1986; Suppl 59:610-2.

19. Norheim G. High productivity analyses of elements in foods using automated digestion and atomic absorption techniqaues. Proceedings of the Fifth European Conference on Food Chemistry. Versailles, France, 1989:2.

20. Salbe $A D$, Hill $C H$, Veillon $C$, Howe $S M$, Longnecker MP, Taylor PR, et al. Relationship between serum somatomedin C levels and tissue selenium content among adults living in a seleniferous area. Nutr Res 1993; 13:399-405.

21. Baxter RC. Circulating binding proteins for the insulinlike growth factors. TEM 1993; 4:91-6.

22. Tarp U, Stengaard-Pedersen K, Hansen JC, Thorling EB. Glutathione redox cycle enzymes and selenium in severe rheumatoid arthritis: lack of antioxidative response to selenium supplementation in polymorphonuclear leukocytes. Ann Rheumatic Dis 1992; 51:1044-9.

23. Thorlacius-Ussing $O$, Danscher $G$. Selenium in the anterior pituitary of rats exposed to sodium selenite: light and electron microscopic localization. Toxicol Appl Pharmacol 1985; 81:67-74.

24. Swanson CA, Patterson BH, Levander OA. Veillon C, Taylor PR, Helzlsouer $\mathrm{K}$, et al. Human ${ }^{74} \mathrm{Se}$ selenomethionine metabolism: a kinetic model. Am J Clin Nutr 1991; 54:917-26.

Helle M. Meltzer

University of Oslo

Nordic School of Nutrition

Faculty of Medicine

P. O. Box 1046

Blindern

N-0316 Oslo

Norway 
